\title{
Evaluation of Growth Hormone Results in Different Diagnosis and Trend Over 10 Year of Follow-up: A Single Center Experience
}

\author{
(D) Zehra Aycan 1,2, (D) Aslıhan Araslı Yılmaz'1, (D) Servet Yel${ }^{1}$, (D) Şenay Savaş-Erdeve ${ }^{1}$, (D) Semra Çetinkaya ${ }^{1}$ \\ 1 University of Health Sciences Turkey, Ankara Dr. Sami Ulus Obstetrics and Gynecology, Children's Health and Diseases Training and Research \\ Hospital, Clinic of Pediatric Endocrinology, Ankara, Turkey \\ ${ }_{2}^{2}$ Ankara University Faculty of Medicine, Department of Pediatric Endocrinology, Ankara, Turkey
}

\begin{abstract}
What is already known on this topic?
Growth hormone $(\mathrm{GH})$ treatment has long been used in rare diseases such as isolated GH deficiency (IGHD), multiple pituitary hormone deficiency (MPHD), small for gestational age (SGA), and Turner syndrome (TS). Early diagnosis and early initiation of GH treatment are important to optimize the effects of treatment.
\end{abstract}

\section{What this study adds?}

Although there are larger series in the literature, our study is one of the largest single-center patient series performed after the The Pfizer International Growth Study database was terminated. GH treatment onset age was late in our cohort and no differences have been observed in the last 10 years. The improvement in the height standard deviation score was seen most in the IGHD and MPHD groups, the least in the TS and SGA groups, the patients' treatment compliance was high (92\%) and the incidence of side effects was low (2.7\%).

\begin{abstract}
Objective: The aim was to evaluate the results of diagnosis, follow-up and treatment of the patients who recieved growth hormone (GH) treatment for the last 10 years and to determine the differences in the process and results over the years.

Methods: Anthropometric, clinical, laboratory data, treatment adherence and side effects were evaluated retrospectively in 767 patients who recieved GH treatment between 2009-2018. Patients were grouped as isolated GH deficiency (IGHD), multiple pituitary hormone deficiency (MPHD), small for gestational age (SGA), and Turner syndrome (TS) depending on diagnosis.

Results: GH treatment was started in 689 cases (89.8\%) with IGHD, 24 (3.1\%) with MPHD, 26 (3.4\%) with SGA and 28 (3.7\%) with TS. Median age of GH treatment onset was the earliest in SGA (8.4 years) and the latest in the IGHD group (12.0 years). At the time of treatment cessation, height standard deviation score (SDS) in IGHD and MPHD was significantly higher than treatment initiation time, whereas there was no significant difference in TS and SGA. One hundred eighty-nine cases reached the final height. Final heights for girls/boys were: IGHD 154/164.9 cm; MPHD 156.2/163.5 cm; TS $146.7 \mathrm{~cm}$; and SGA $145.7 /$-cm, respectively. Target height SDS-final height SDS median values were IGHD: 0.1, MPHD: 0.6, SGA: 0.5, TS: 2.4 respectively. The patients' treatment compliance was high $(92 \%)$ and the incidence of side effects was low $(2.7 \%)$.

Conclusion: In our cohort, GH treatment start age was late and no difference in this was observed in the last 10 years. The improvement in the height SDS was most marked in the IGHD and MPHD groups, the least in the TS and SGA groups.
\end{abstract}

Keywords: Rare disease, growth hormone treatment, follow-up

Address for Correspondence: Aslihan Araslı Y1lmaz MD, University of Health Sciences Turkey, Ankara Dr. Sami Ulus Obstetrics and Gynecology, Children's Health and Diseases Training and Research Hospital, Clinic of Pediatric Endocrinology, Ankara, Turkey

Phone: +90 5326487709 E-mail: draslihanarasli@hotmail.com ORCID: orcid.org/0000-0003-4403-2381
Conflict of interest: None declared Received: 13.10 .2020 Accepted: 25.02.2021 


\section{Introduction}

The introduction of recombinant human growth hormone $(\mathrm{GH})$ in 1985 ended the phase of pituitary-derived human $\mathrm{GH}$ and its associated limitations and risks, opening the possibility of widespread clinical use (1). GH treatment has long been used in rare diseases, such as isolated GH deficiency (IGHD), multiple pitutiary hormone deficiency, (MPHD), small for gestational age (SGA), and Turner syndrome (TS). Today, it is also used in other indications such as chronic renal failure, SHOX deficiency, PraderWilli syndrome and idiopathic short stature, besides $\mathrm{GH}$ deficiency (GHD) (2).

The foremost aims of $\mathrm{GH}$ treatment in children are the normalization of height during childhood, attainment of a timely and normal pubertal growth and the achievement of an adult height that is normal for the population and genetic target, in conjunction with normalization of other aspects, such as body composition, metabolism and quality of life (1). In all pediatric indications, early diagnosis and early initiation of $\mathrm{GH}$ treatment are important to optimize the effects of treatment.

The Pfizer International Growth Study (KIGS) (3), the National Cooperative Growth Study (4) and the NordiNet International Outcome Study (5), are multicenter, international databases created to monitor the efficacy and safety of GH treatment. The advantage of these databases is to create a standardized, common platform for uniform documentation of data on $\mathrm{GH}$ treatment in centers participating in the database, potentially reveal differences between clinics, and offer the possibility of reliable observation of potentially rare results due to the large number of participants (6). The KIGS database, in which data entries were made from many centers in our country and where we evaluate the treatment results of patients with GH treatment was terminated approximately 10 years ago. However, there are no new outputs regarding the diagnosis and treatment processes of these diseases in our country in recent years. In this study, we aimed to determine the follow-up, and treatment results and final heights of patients with rare diseases who had been treated with GH treatment in the last 10 years, and to determine the differences in the process and results over the years.

\section{Methods}

In the present study, 767 patients who had received GH treatment in Ankara Dr. Sami Ulus Obstetrics and Gynecology, Children's Health and Disease Training and Research Hospital between 2009 and 2018 were recruited. The study was conducted in accordance with the principles of the Declaration of Helsinki and approved by a Ankara Keçiören Training and Research Hospital Local Ethics Committee (no: 1686, date: 23.05.2018). Anthropometric, clinical, laboratory findings, treatment adherence and side effects of patients during, admission, $\mathrm{GH}$ treatment initiation time, follow-up, and $\mathrm{GH}$ treatment cessation time were evaluated retrospectively. Patients were grouped by diagnosis as IGHD, MPHD, TS, and SGA

After systemic disease screening, at least two different $\mathrm{GH}$ stimulation tests were performed in patients with pathological short stature whose growth rate $<25^{\text {th }}$ percentile and height standard deviation score (SDS) $<-2.5$. Apart from these, height SDS $>-2.5$ but with a growth rate below -2 SDS in the last year or below -1.5 SDS in the last two years, cases thought to have GHD, and patients with a regression in growth rate for more than six months clinically and genetically confirmed TS were also evaluated $(7,8)$. Before the last change in the social security institution regulation regarding TS and SGA patients, two different GH tests were required from all patients in order to pay for $\mathrm{GH}$ treatment in our country. Since TS and SGA patients included in the study were diagnosed before these changes related to these patients, all patient groups, including TS and SGA cases, were administered a GH stimulation test.

GHD was defined as $<10 \mathrm{ng} / \mathrm{mL}$ serum peak $\mathrm{GH}$ concentration (7). It was required that the bone age should be at least 2 years retarded compared to chronologic age in the prepubertal period, and the epiphyseal plates were open in puberty. In addition, male and female subjects were primed with sex steroids prior to provocative GH testing, particularly in the patients with delayed puberty. For both boys and girls, $2 \mathrm{mg} \beta$-oestradiol (1 $\mathrm{mg}$ for body weight $<20 \mathrm{~kg}$ ) (not ethinyl oestradiol) was administered orally on each of the two evenings preceding the test, while boys were also given intramuscular testosterone (50-100 mg of a depot formulation administered one week before the test). Puberty was defined as breast development $\geq 2$ Tanner stage in girls and testicular volume $\geq 4 \mathrm{~mL}$ in boys (9).

IGHD was defined as a condition of GHD not associated with other pituitary hormone deficiencies. MPHD was defined as a deficiency of at least two pituitary hormones, with one being GH. SGA was defined as birth weight less than -2 SDS for gestational age. TS was defined as females who have partial or complete absence of the second sex chromosome with a variety of phenotypic features.

All measurements were calculated with the reference developed for Turkish children and expressed as SDS $(10,11)$. Target (mid-parental) height was calculated by adding $6.5 \mathrm{~cm}$ to the mean of the parents' heights for boys 
or by subtracting $6.5 \mathrm{~cm}$ from the mean of the parents' heights for girls (12). If those who reached the final height were within range of $\pm 5 \mathrm{~cm}$ of the target height, they were considered as having reached target height.

After GH tests were evaluated, organic pathology that may accompany cases with GH deficiency was evaluated by performing pituitary magnetic resonance imaging (MRI). $\mathrm{GH}$ was administered subcutaneously at a dose range of 0.2-0.4 $\mathrm{mg} / \mathrm{kg} /$ week, six days per week. According to the rules of the social security institution in our country, the $\mathrm{GH}$ treatment is discontinued when height reaches $155 \mathrm{~cm}$ in girls and $165 \mathrm{~cm}$ in boys. In addition, $\mathrm{GH}$ treatment was discontinued if the annual growth rate was $<2 \mathrm{~cm}$ and/or bone age was $\geq 16$ in boys and $\geq 14$ in girls (7).

$\mathrm{GH}$ product, type of injection device, dosage, GH storage conditions, number of missed injections, reasons for missed injections, person administering daily GH injections and problems in follow-up were recorded at each visit and patients' compliance was evaluated. Adherence categories were established following the criteria of Smith et al (13), and patients were categorized into one of four compliance groups, based on the percent of doses omitted at each evaluation period: excellent if $0 \%$, good if $5 \%$, fair if 5 to $10 \%$, and poor if $>10 \%$. Patients in the poor category were considered to be incompatible with treatment.

\section{Statistical Analysis}

The Predictive Analytics Software 18, (2009) program was used for statistical analysis. The conditions where the type1 error level was below 5\% were interpreted statistically. Kolmogorov-Smirnov and Shapiro-Wilk tests were used for assessment of normality of distribution of the data. In descriptive statistics, categorical variables are expressed as number and percentage, and numerical variables are presented as median, and minimum and maximum values. Student's t-test was used to compare two groups when the parametric test prerequisites were met and Mann-Whitney $\mathrm{U}$ test was used otherwise. The Friedman test was used to examine the change in the age, bone age, height SDS, body mass index (BMI) SDS, puberty, and follow-up time, $\mathrm{GH}$ treatment initiation time, and $\mathrm{GH}$ treatment cessation time separately in all patients and groups. The Wilcoxon signed-ranks test was used in post-hoc analysis. Bonferroni correction was used in post-hoc analysis whenever appropriate. In all patients and in the IGHD group, the Kruskal-Wallis test was used for comparison analysis of numerical values between date groups. To evaluate the relationship between final height-SDS and target height SDS, first year growth velocity, treatment duration, age at GH treatment initiation, bone age, height SDS, puberty, gender, and concentrations of insulin-like growth factor-1 (IGF-1), IGF binding protein 3 (IGFBP3), multiple linear regression analysis was performed with the backward method. A p value $<0.05$ was considered statistically significant.

\section{Results}

The median age of patients (63\% male) who were admitted to the clinic due to short stature was 10.4 years at first visit. $\mathrm{GH}$ treatment was started in 689 cases $(89.8 \%)$ with IGHD, $24(3.1 \%)$ with MPHD, 26 (3.4\%) with SGA, and $28(3.7 \%)$ with TS. The median age of GH treatment start was 12.0 years, the earliest was in SGA (8.4 years) and the latest was in IGHD (12.0 years). When the age of first admission to the hospital and the GH treatment onset age were compared by year, it was found that there was no difference between them at the beginning or at the end of the 10 years study period $(p>0.05)$ (Table 1$)$.

The height SDS at the GH treatment initiation time was below $<-2.5$ in the entire group and subgroups. The lowest height SDS was in the MPHD group, and the height SDS values of TS, and SGA groups were lower than the IGHD group. The lowest peak response to GH tests was in the MPHD, IGHD, and TS groups, respectively. The lowest serum IGF-1 and IGFBP3 values were in the MPHD group. The serum IGF-1 level was <-2 SDS in 330 (43.9\%) patients, between -2 SDS and -1 SDS in $380(50.5 \%)$ patients, and >-1 SDS in 42 (5.6\%) patients (Table 2 ).

The pituitary MRI was pathological in $27.1 \%$ of the patients, and the most common accompanying pathology was pituitary hypoplasia (60\%). Various pathologies, including pituitary hypoplasia, ectopic neurohypophysis, microadenoma/suspected microadenoma, empty sella, partial empty sella, Rathke cleft cyst, and arachnoid cyst, were detected in $25.9 \%$ of patients with IGHD and $78.3 \%$ of patients with MPHD. Patients with suspected microadenoma and microadenoma underwent neurosurgery consultation before GH treatment. In none of the cases, organic pathology that could interfere with GH treatment was found on MRI.

The median follow-up time without treatment was 11 months and the median follow-up time with treatment was 2.1 years. The longest duration of treatment was in the MPHD group at 3.8 (range, 0.3-9) years, and the shortest duration of treatment was in the IGHD group at 2 (range, 0.3-10.8) years. The median treatment dose was 0.2 (range, 0.2-0.4) $\mathrm{mg} / \mathrm{kg} /$ week in the entire group and subgroups, while it was $0.3 \mathrm{mg} / \mathrm{kg} /$ week in the TS group. During the treatment, the changes in patients' GH dose were minimal (7.0\%) and the 
doses of GH were adjusted in relation to weight, elevation of IGF-1 concentration or changes in glucose metabolism.

Growth velocity was highest in the first year of treatment in the entire group and subgroups, and gradually decreased in the following years. The median value of the first-year growth velocity was $8.2 \mathrm{~cm} /$ year in entire group, while it was $9.8 \mathrm{~cm} /$ year in MPHD, $8.3 \mathrm{~cm} /$ year in IGHD, $7.8 \mathrm{~cm} /$ year in TS and $7.1 \mathrm{~cm} /$ year in SGA.

\begin{tabular}{|c|c|c|c|c|c|c|c|c|}
\hline \multirow[t]{2}{*}{ year } & \multicolumn{2}{|c|}{$\begin{array}{l}\text { Age at admission-entire } \\
\text { group }\end{array}$} & \multicolumn{2}{|c|}{$\begin{array}{l}\text { Age at start of treatment- } \\
\text { entire group }\end{array}$} & \multicolumn{2}{|c|}{$\begin{array}{l}\text { Age at presentation } \\
\text { IGHD group }\end{array}$} & \multicolumn{2}{|c|}{$\begin{array}{l}\text { Age at start of treatment } \\
\text { IGHD group }\end{array}$} \\
\hline & $n$ & Median (min-max) & $n$ & Median (min-max) & $\mathrm{n}$ & Median (min-max) & $\mathrm{n}$ & Median (min-max) \\
\hline 2009 & 23 & $9.9(3.6-17)$ & 23 & $11.5(4-17.3)$ & 18 & $10.1(4-17)$ & 18 & $11.5(4.2-17.3)$ \\
\hline 2010 & 84 & $9.7(0.1-15.4)$ & 84 & $11.7(4.6-16.3)$ & 68 & $10.2(2.9-15.4)$ & 68 & $12(4.6-16.3)$ \\
\hline 2011 & 98 & $10.9(1.8-16.6)$ & 98 & $12(5.1-17)$ & 92 & $10.8(1.8-16.6)$ & 92 & $12(5.1-17)$ \\
\hline 2012 & 86 & $10.7(0.2-15.6)$ & 86 & $1.8(0.8-16.4)$ & 77 & $10.8(0.6-15.6)$ & 77 & $11.8(0.8-16.4)$ \\
\hline 2013 & 104 & $11(0-16.8)$ & 104 & $12(1.4-16.9)$ & 95 & $11.1(1-16.8)$ & 95 & $12.1(1.4-16.9)$ \\
\hline 2014 & 93 & $11.1(0-15.6)$ & 93 & $12.2(2.1-17)$ & 88 & $11.2(0.5-15.6)$ & 88 & $12.2(2.1-16)$ \\
\hline 2015 & 83 & $10.5(0-15.8)$ & 83 & $12(3.1-16.5)$ & 78 & $10.7(2-15.8)$ & 78 & $12.2(3.1-16.5)$ \\
\hline 2016 & 70 & $9.1(0.3-15.1)$ & 70 & $11.8(2-16.4)$ & 60 & $9.2(0.8-15.1)$ & 60 & $12(2.5-16.4)$ \\
\hline 2017 & 87 & $9.3(0-16)$ & 87 & $11.7(3.1-16.6)$ & 80 & $9.8(0-16)$ & 80 & $11.7(3.1-16.6)$ \\
\hline 2018 & 39 & $11.3(2.7-15.7)$ & 39 & $12.8(3.7-16)$ & 33 & $11.6(3.3-15.7)$ & 33 & $12.8(5.1-16)$ \\
\hline $\mathrm{p}$ & \multicolumn{2}{|c|}{0.091} & \multicolumn{2}{|c|}{0.232} & \multicolumn{2}{|c|}{0.294} & \multicolumn{2}{|c|}{0.472} \\
\hline
\end{tabular}

IGHD: isolated growth hormone deficiency, min-max: minimum-maximum

Table 2. Anthropometric and laboratory features of patients at start of growth hormone therapy

\begin{tabular}{|c|c|c|c|c|c|}
\hline & $\begin{array}{l}\text { Entire group } \\
(\mathrm{n}=767)\end{array}$ & IGHD $(n=689)$ & MPHD $(n=24)$ & SGA $(n=26)$ & TS $(n=28)$ \\
\hline Chronologic age (years) & $12(0.83-17.3)$ & $12.0(0.83-17.3)$ & $9.3(1.8-17)$ & $8.4(3.0-14.4)$ & $10.6(2.4-15.4)$ \\
\hline Bone age (years) & $9(0.5-15)$ & $10(0.5-15)$ & $5(0.5-13.5)$ & $5.3(1.1-13.5)$ & $8.1(2-13)$ \\
\hline \multirow[t]{2}{*}{ Sex n/\% (female) (male) } & $289(37.7)$ & $240(34.8)$ & $6(25)$ & $15(57.7)$ & $28(100)$ \\
\hline & $478(62.3)$ & $449(65.2)$ & $18(75)$ & $11(42.3)$ & $0(0)$ \\
\hline Birth weights SDS & $0.09(-3.30-3.19)$ & $0.11(-1.97-3.19)$ & $0.09(-1.96-1.42)$ & $-2.45(-3.30--2.02)$ & $-0.47(-1.72-1.17)$ \\
\hline Height SDS & $-3(-8.5--1.0)$ & $-2.9(-8.5--1.7)$ & $-3.8(-7.8--1)$ & $-3.4(-5.9--2.5)$ & $-3.4(-6.9--1.82)$ \\
\hline BMI SDS & $-0.8(-6.3-3.6)$ & $-0.9(-6.3-3.6)$ & $0.2(-4-3.2)$ & $-1.21(-2.8-1.7)$ & $0.7(-2.8-1.9)$ \\
\hline Tanner stage & $1(1-5)$ & $1(1-5)$ & $1(1-2)$ & $1(1-5)$ & $1(1-2)$ \\
\hline L-dopa-peak GH (ng/mL) & $3.86(0.01-18.9)$ & $3.86(0.01-9.88)$ & $0.48(0.07-9.6)$ & $9.5(0.46-18.9)$ & $3.66(0.55-11.4)$ \\
\hline Clonidine peak $\mathrm{GH}(\mathrm{ng} / \mathrm{mL})$ & $5.05(0-25.1)$ & $5.05(0.02-9.74)$ & $0.52(0.13-9.11)$ & $11.36(0-25.1)$ & $5.19(0.73-10.1)$ \\
\hline ITT peak GH (ng/mL) & $1.8(0-10.4)$ & $1.8(0.04-9.67)$ & $0.3(0-1.7)$ & $6.39(1.1-10.4)$ & $2.46(0.28-7.66)$ \\
\hline Serum IGF-1 (ng/mL) & $146.3(11.5-555)$ & $148(11.5-555)$ & $50.1(16.9-231)$ & $117(37.3-222)$ & $147(43.3-375)$ \\
\hline IGF-1 SD $<-2(n / \%)$ & $330(43.9 \%)$ & $303(44.6 \%)$ & $16(80 \%)$ & $7(26.9 \%)$ & $4(15.4)$ \\
\hline $\begin{array}{l}\text { IGF-1 SD -1 to }-2(\%) \\
(\mathrm{n} / \%)\end{array}$ & $380(50.5 \%)$ & $340(50 \%)$ & $4(20 \%)$ & $17(65.4 \%)$ & $19(73.1)$ \\
\hline $\begin{array}{l}\text { IGF-1 SD >-1 (\%) } \\
(\mathrm{n} / \%)\end{array}$ & $42(5.6)$ & $37(5.4 \%)$ & $0(0 \%)$ & $2(7.7 \%)$ & $3(11.5)$ \\
\hline Serum IGFBP3 (ng/mL) & $3840(49.4-8800)$ & $3890(49.4-8800)$ & $1470(500-5570)$ & $\begin{array}{l}3245.5(1800- \\
6120)\end{array}$ & $\begin{array}{l}3759(1340- \\
6780)\end{array}$ \\
\hline IGFBP3 SD $<-2(n / \%)$ & $83(11.1 \%)$ & $72(10.5 \%)$ & $11(55 \%)$ & $0(0 \%)$ & $1(3.9)$ \\
\hline IGFBP3 SD -1 to -2 & & & & & \\
\hline$(\mathrm{n} / \%)$ & $489(65.5 \%)$ & $454(67.3 \%)$ & $7(35 \%)$ & $14(53.8 \%)$ & $14(53.8)$ \\
\hline $\begin{array}{l}\text { IGFBP3 SD > }>-1 \\
(n / \%)\end{array}$ & $175(23.4 \%)$ & $150(22.2 \%)$ & $2(10 \%)$ & $12(46.2 \%)$ & $11(42.3)$ \\
\hline
\end{tabular}


Considering GH treatment cessation time, height SDSs in IGHD and MPHD groups were significantly higher than at treatment start ( $p<0.001)$, whereas there was no significant difference in TS $(p=0.225)$ and SGA groups $(p=0.191)$. In the same period, no statistically significant difference was found in terms of the BMI SDS in the subgroups, except for the IGHD group (Table 3).

In total 189 patients reached final height; by diagnosis subgroup this was IGHD $n=166$, TS $n=11$, MPHD $n=8$, SGA $n=4$. Except for the TS and SGA groups, the percentage of patients reaching final height was higher in boys. In groups outside TS and SGA, final height SDSs were above -2 SDS. Final height for girls/boys were as follows: IGHD: 154/164.9 cm, MPHD: $156.2 / 163.5 \mathrm{~cm}$, TS:146.7 (range, 133-156.4) $\mathrm{cm}$, and SGA:145.7 (range, 136.7-150.3) cm. Of the 166 IGHD patients who reached final height, $104(67.5 \%)$ were found to reach their target height. Target height SDSfinal height SDS was the greatest in the TS group and the proportion reaching final height was the lowest in the TS

Table 3. Anthropometric and clinical findings of patients at first presentation, growth hormone therapy start and growth hormone therapy cessation

\begin{tabular}{|c|c|c|c|c|c|c|}
\hline & & $\mathrm{n}$ & $\begin{array}{l}\text { Admission } \\
\text { median (min-max) }\end{array}$ & $\begin{array}{l}\text { GH treatment start time } \\
\text { median (min-max) }\end{array}$ & $\begin{array}{l}\text { GH treatment offset } \\
\text { time median (min- } \\
\text { max) }\end{array}$ & $\mathrm{p}$ \\
\hline \multirow{6}{*}{ 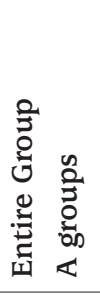 } & Age (years) & 499 & $11.2(0-17)^{\mathrm{bc}}$ & $12.2(0.8-17.3)^{\mathrm{ac}}$ & $15.1(2.9-21)^{\mathrm{ab}}$ & $<0.001$ \\
\hline & Bone age (years) & 449 & $8.1(0-15)^{\mathrm{bc}}$ & $10(0.8-15)^{\mathrm{ac}}$ & $14(1-17)^{\mathrm{ab}}$ & $<0.001$ \\
\hline & Height SDS & 499 & $-2.9(-8.5-1.8)^{b c}$ & $-3(-8.5-1.7)^{\mathrm{ac}}$ & $-2(-7.2-1)^{\mathrm{ab}}$ & $<0.001^{*}$ \\
\hline & BMI SDS & 498 & $-0.9(-5.5-4)^{c}$ & $-1(-6.3-3.6)$ & $-0.8(-10.2-4.2)^{b}$ & $0.005^{*}$ \\
\hline & Puberty & 495 & $1(1-5)^{c}$ & $1(1-5)^{c}$ & $4(1-5)^{\mathrm{ab}}$ & $<0.001^{*}$ \\
\hline & Follow-up (year) & 767 & - & $0.9(0-12.5)$ & $2.1(0.3-10.8)$ & $<0.001$ \\
\hline \multirow{6}{*}{ 思 } & Age (years) & 453 & $11.4(0.6-17)^{\mathrm{bc}}$ & $12.3(0.8-17.3)^{\mathrm{ac}}$ & $15.1(2.9-19)^{\mathrm{ab}}$ & $<0.001^{*}$ \\
\hline & Bone age (years) & 407 & $8.1(0-15)^{\mathrm{bc}}$ & $10(0.8-15)^{\mathrm{ac}}$ & $14(1-17)^{\mathrm{ab}}$ & $<0.001^{*}$ \\
\hline & Height SDS & 453 & $-2.8(-8.5-0.2)^{b c}$ & $-3(-8.5-1.7)^{\mathrm{ac}}$ & $-1.9(-7.1-1)^{\mathrm{ab}}$ & $<0.001$ \\
\hline & BMI SDS & 452 & $-0.9(-4.3-3.5)$ & $-1(-6.3-3.6)^{c}$ & $-0.8(-10.2-4.2)^{b}$ & 0.011 * \\
\hline & Puberty & 449 & $1(1-5)^{c}$ & $1(1-5)^{c}$ & $4(1-5)^{a b}$ & $<0.001$ \\
\hline & Follow-up (year) & 689 & - & $0.9(0-12.5)$ & $2.1(0.3-10.8)$ & $<0.001^{*}$ \\
\hline \multirow{6}{*}{ 空 } & Age (years) & 15 & $7.2(0-14.9)^{\mathrm{bc}}$ & $9.9(1.8-17)^{\mathrm{ac}}$ & $16.3(3.8-21)^{\mathrm{ab}}$ & $<0.001 *$ \\
\hline & Bone age (years) & 13 & $5(1-11)^{c}$ & $6(2.9-13.5)^{c}$ & $14(7-17)^{\mathrm{ab}}$ & $<0.001 *$ \\
\hline & Height SDS & 15 & $-3.5(-5.98--0.97)^{\mathrm{bc}}$ & $-3.84(-6.08--2.18)^{\mathrm{ac}}$ & $-1.69(-6.3--0.24)^{\mathrm{ab} a b}$ & $<0.001^{*}$ \\
\hline & BMI SDS & 15 & $-0.2(-2.4-1.9)$ & $-0.52(-2.39-1.91)$ & $-0.16(-3.38-1.54)$ & 0.207 \\
\hline & Puberty & 15 & $1(1-2)^{c}$ & $1(1-2)^{c}$ & $3(1-5)^{\mathrm{ab}}$ & $0.007^{*}$ \\
\hline & Follow-up (year) & 24 & - & $1.5(0-6.8)$ & $3.8(0.3-9)$ & $0.023 *$ \\
\hline \multirow{6}{*}{ త్ర } & Age (years) & 14 & $9.01(0.19-14.01)^{b c}$ & $10.35(3.01-14.4)^{\mathrm{ac}}$ & $13.91(5.1-17.3)^{\mathrm{ab}}$ & $<0.001^{*}$ \\
\hline & Bone age (years) & 13 & $8.1(1.6-13.6)^{c}$ & $9(1.06-13.5)^{c}$ & $14(3-16)^{\mathrm{ab}}$ & $<0.001^{*}$ \\
\hline & Height SDS & 14 & $-3.87(-5.81--2.6)$ & $-3.84(-5.87--2.49)$ & $-3.11(-7.2--1.9)$ & 0.191 \\
\hline & BMI SDS & 14 & $-1.2(-3.7-4)$ & $-1.67(-2.64-0.97)$ & $-1.21(-3.08-1.82)$ & 0.257 \\
\hline & Puberty & 17 & $1(1-3)^{c}$ & $1(1-3)^{c}$ & $2(1-5)^{\mathrm{ab}}$ & $0.040 *$ \\
\hline & Follow-up (year) & 26 & - & $1.5(0.1-5.3)$ & $2.4(0.5-8.3)$ & $0.038 *$ \\
\hline \multirow[b]{6}{*}{$\mathscr{H}$} & Age (years) & 17 & $9.4(0-13.6)^{\mathrm{bc}}$ & $11.11(7-13.8)^{\mathrm{ac}}$ & $14.6(7.3-17)^{\mathrm{ab}}$ & $<0.001 *$ \\
\hline & Bone age (years) & 16 & $7.6(0.5-13)^{c}$ & $8.1(5-13)^{\mathrm{c}}$ & $13.5(10-15)^{\mathrm{ab}}$ & $<0.001 *$ \\
\hline & Height SDS & 17 & $-3.42(-4.33-1.79)$ & $-3.5(-4.33--1.95)$ & $-2.85(-5.2--1.1)$ & 0.225 \\
\hline & BMI SDS & 17 & $0.7(-5.5-1.7)$ & $0.75(-1.22-1.9)$ & $0.4(-1.16-2.41)$ & 0.814 \\
\hline & Puberty & 17 & $1(1-2)^{c}$ & $1(1-2)^{c}$ & $4(1-5)^{\mathrm{ab}}$ & 0.001 * \\
\hline & Follow-up (year) & 28 & - & $0.5(0-11)$ & $2.8(0.3-6.3)$ & $0.008 *$ \\
\hline
\end{tabular}


group (Table 4). The change in height SDS of the patients from the beginning of treatment to the final height is given in Figure 1.

Of our IGHD patients who reached their final height, 93 (56.0\%) were prepubertal and 73 (44\%) were pubertal at the beginning of $\mathrm{GH}$ treatment. At the time of initiation of GH treatment, the age and bone age of pubertal IGHD patients were significantly higher than in prepubertal IGHD patients $(p<0.001)$. The duration of treatment was longer in prepubertal IGHD patients than in pubertal patients $(p<0.001)$ (Table 5). There was no statistically significant difference between prepubertal and pubertal IGHD patients in terms of height SDS, BMI SDS, final height SDS, target height-SDS, first year growth velocity and treatment dose.

In multiple linear regression analysis, $\mathrm{GH}$ treatment start time height SDS, target height SDS, first year growth velocity and puberty status were predictive factors for final height SDS (Table 6).

Patients' compliance with treatment was high (92\%), and treatment was interrupted in $16 \%$ of patients due to problems in compliance with treatment during treatment,

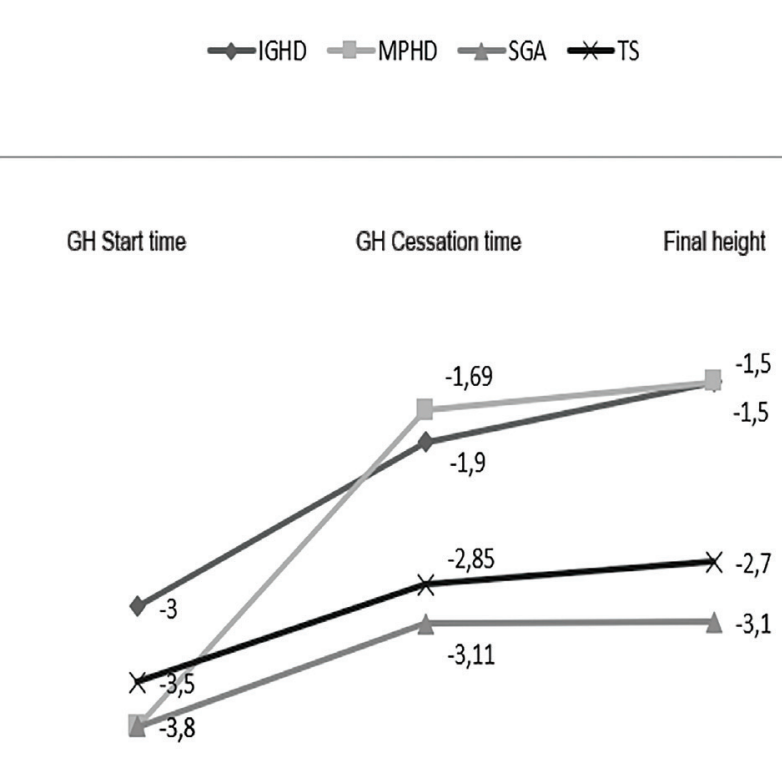

Figure 1. Graph of changes in height standard deviation score values of the groups

IGHD: isolated growth hormone deficiency, GH: growth hormone, SGA. small for gestational age, MPHD: multiple pitutiary hormone deficiency, TS: Turner syndrome

\begin{tabular}{|c|c|c|c|c|c|}
\hline & $\begin{array}{l}\text { Entire group } \\
(n=189)\end{array}$ & IGHD $(n=166)$ & MPHD $(n=8)$ & SGA $(n=4)$ & TS $(n=11)$ \\
\hline Age (years) & $17(12.7-23)$ & $17(12.7-23)$ & $17.8(14.6-19.6)$ & $16.3(14.9-18)$ & $16.4(15-18)$ \\
\hline Bone age (years) & $16(12.5-17.4)$ & $16(13.6-17.4)$ & $16(12.5-16)$ & 16 & - \\
\hline \multicolumn{6}{|l|}{ Sex } \\
\hline Female & $95(50.3)$ & $77(46.4)$ & $3(37.5)$ & $4(100)$ & $11(100)$ \\
\hline Male & $94(49.7)$ & 89 (53.6) & $5(62.5)$ & $0(0)$ & $0(0)$ \\
\hline FH (girl) & $153.3(133-170.8)$ & $154(137.5-170.8)$ & $156.2(150-160.6)$ & $145.7(136.7-150.3)$ & $146.7(133-156.4)$ \\
\hline FH (boy) & $164.9(146.7-173.2)$ & $164.9(152-173.2)$ & $163.5(146.7-171.8)$ & - & - \\
\hline FH SDS & $-1.6(-4.6-0.7)$ & $-1.5(-3.5-0.7)$ & $-1.5(-2.5-0.4)$ & $-3.1(-4.5--2.1)$ & $-2.7(-4.6-1.2)$ \\
\hline TH SDS & $-1.5(-3.4-0.5)$ & $-1.5(-3.4-0.5)$ & $-1.1(-1.8-0.3)$ & $-2(-3.4-1.06)$ & $-1.2(-1.7-0.1)$ \\
\hline TH-FH SDS & $0.2(-2.3-3.4)$ & $0.1(-2.3-3)$ & $0.6(-1.2-1.8)$ & $0.5(-0.1-2.8)$ & $2.4(0.4-3.4)$ \\
\hline BMI & $20.4(15-37.6)$ & $20.1(15-33)$ & $23.4(16.7-26.6)$ & $19.3(18.9-20.7)$ & $24.2(19.2-37.6)$ \\
\hline BMI SDS & $-0.6(-4.2-4.3)$ & $-0.7(-4.2-3.8)$ & $0.5(-3.1-1.6)$ & $-0.6(-1.5-1.5)$ & $0.7(-1.1-4.3)$ \\
\hline Puberty & $5(2-5)$ & $5(3-5)$ & $4(2-5)$ & $5(4-5)$ & $5(3-5)$ \\
\hline $\begin{array}{l}\text { Age at start of } \\
\text { treatment }\end{array}$ & $12.4(4-17.3)$ & $12.5(5.4-17.3)$ & $9(4-17)$ & $12.3(12.1-13.9)$ & $11.1(8.4-13.2)$ \\
\hline $\begin{array}{l}\text { Duration of } \\
\text { treatment (year) }\end{array}$ & $2.9(0.2-12)$ & $2.8(0.2-12)$ & $6(1.5-9)$ & $1.9(1-4)$ & $4.5(1.3-6.3)$ \\
\hline $\begin{array}{l}\text { Treatment dose } \\
(\mathrm{mg} / \mathrm{kg} / \mathrm{wk})\end{array}$ & $0.2(0.2-0.4)$ & $0.2(0.2-0.3)$ & $0.2(0.2-0.2)$ & $0.2(0.2-0.3)$ & $0.3(0.2-0.4)$ \\
\hline $\begin{array}{l}\text { Not reaching target } \\
\text { height }\end{array}$ & $62(35.8)$ & $50(32.5)$ & $3(42.9)$ & $2(50)$ & $7(87.5)$ \\
\hline $\begin{array}{l}\text { Reaching target } \\
\text { height }\end{array}$ & $111(64.2)$ & $104(67.5)$ & $4(57.1)$ & $2(50)$ & $1(12.5)$ \\
\hline
\end{tabular}


low growth rate, and high IGF-1. Treatment incompatibility was lowest in the IGHD group and highest in the SGA group. Adverse effects were seen in $2.7 \%(n=21)$ of our patients. These side effects were; significant creatinine kinase elevation $(n=8)$, scoliosis $(n=5)$, cardiac causes $(n=2$ with one each of subaortic segmental hypertrophy and left ventricular hypertrophy), orthopedic causes including slipped capital femoral epiphysis $(n=1)$ and Osgood-Schlatter's disease $(n=1)$, non-injection site rash $(n=2)$, disorders of glucose metabolism $(n=1$, impaired fasting glucose) and malignancy ( $n=1$, osteochondroma). Both patients with cardiac side effects were in the IGHD group and neither had syndromic features. Scoliosis, slipped capital femoral epiphysis and impaired fasting glucose were thought to be related to GH treatment. Scoliosis was newly developed in four cases and an increase in existing scoliosis in one case. Our patient with malignancy was followed up because of TS, the total treatment duration was 2.92 years, and the treatment dose was $0.3 \mathrm{mg} / \mathrm{kg} /$ week. It was found that the patient, whose treatment was discontinued after malignancy was detected, did not continue with her subsequent follow-ups.

\section{Discussion}

Our study, which is the second largest of pediatric patients receiving GH from Turkey, after the Turkey KIGS Database analysis published in 2004 with 1008 patients, evaluated etiology and treatment outcomes (14). In our study, in keeping with earlier reports, the highest proportion of patients were in the IGHD group and patients were mostly male $(14,15)$.

It has been shown that the age at initiation of GH treatment is correlated negatively with the response to treatment, which emphasizes the need for early diagnosis and treatment (7). In a recently study by Sävendahl et al (16) data from the American Norditropin Studies: Web-Enabled Research Program (ANSWER-USA) and the NordiNet International Outcome Study (NordiNet IOS-Europe) were compared. Growth hormone initiation age in GHD, TS, and SGA patients were 11.09, 8.92 and 9.0 years in the ANSWER trial, respectively, while it was $9.12,8.72$ and 7.92 years in the NORDINET-IOS trial, respectively. The authors concluded that starting age of GH therapy was higher in all indications in the USA. Pfäffle et al (17) reported that the age of initiation of treatment was similar between the USA and Germany, but higher in the indications in France. Data

Table 5. Comparison of isolated growth hormone deficiency patients reaching final height according to their puberty status at the beginning of treatment

\begin{tabular}{llll}
\hline & $\begin{array}{l}\text { Prepubertal }(\mathbf{n}=93) \\
\text { median }(\text { min-max) }\end{array}$ & $\begin{array}{l}\text { Pubertal }(\mathbf{n}=73) \\
\text { median }(\text { min-max })\end{array}$ & $\mathbf{p}$ \\
\hline Age (years) & $12(5.4-14.4)$ & $14(11.11-17.3)$ & $<0.001$ \\
Bone age (years) & $8.1(3-10)$ & $12(10.50-15.00)$ & $<0.001$ \\
Height SDS & $-3.00(-5.54-2.39)$ & $-2.81(-5.10-1.70)$ & 0.140 \\
BMI SDS & $-1.16(-3.91-1.98)$ & $-1.14(-5.03-1.70)$ & 0.912 \\
TH SDS & $-1.63(-3.38-0.13)$ & $-1.23(-3.03-0.49)$ & 0.052 \\
FH SDS & $-1.59(-3.10-0.13)$ & $-1.42(-3.5-0.70)$ & 0.444 \\
First year growth velocity (cm) & $8.5(3.9-11.8)$ & $8.7(2.0-11.6)$ & 0.867 \\
Duration of treatment (year) & $3.5(1.4-9)$ & $2.00(0.3-4.8)$ & $<0.001$ \\
Treatment dose (mg/kg/wk) & $0.2(0.2-0.3)$ & $0.2(0.2-0.3)$ & 0.335 \\
\hline
\end{tabular}

SDS: standard deviation score, BMI: body mass index, TH: target height, FH: final height, wk: week, min-max: minimum-maximum

\begin{tabular}{|c|c|c|c|c|c|}
\hline \multicolumn{6}{|l|}{$\mathrm{R}^{2}=0.377 \mathrm{p}<0.001$} \\
\hline Variable & $\mathrm{B}$ & SE & Beta & $\mathrm{t}$ & $\mathrm{p}$ \\
\hline TH SDS & 0.161 & 0.080 & 0.139 & 2.019 & 0.045 \\
\hline Bone age (year) & -0.078 & 0.042 & -0.195 & -1.847 & 0.067 \\
\hline Height SDS at GH treatment start & 0.482 & 0.093 & 0.358 & 5.199 & $<0.001$ \\
\hline Puberty & -0.168 & 0.076 & -0.161 & -2.209 & 0.029 \\
\hline First year growt velocity (cm/year) & 0.144 & 0.035 & 0.278 & 4.105 & $<0.001$ \\
\hline
\end{tabular}


from these different analyses show that the average age at the start of GH treatment is higher than desired worldwide.

In the study in which patients were registered in the KIGS database in Turkey and were treated with $\mathrm{GH}$, the age at onset of GH treatment was 11.3 years (14), and $11.2 \pm 2.67$ years in the study performed by Soyöz and Dündar (18). In our study, the median age at onset of treatment was 12.0 years; the age at onset of treatment was oldest in the IGHD group and youngest in the SGA group, and there was no difference in the ages at first presentation and at initiation of treatment in the last 10 years. Our findings show that despite the increase in health awareness and easier access to health services in recent years, age at onset of GH treatment is still late in our cohort.

In our study, the highest growth velocity in the first year of treatment was in the MPHD and IGHD groups, besides height SDS was -3.0 and -3.84 in patients in the IGHD and MPHD groups at the GH treatment onset time, while the final height SDS was -1.5 in both of these groups. In previous studies from Turkey final height SDSs in IGHD and MPHD were found to be -1.8 and -1.6 by Kurnaz et al (19) and -1.4 and -1.1 by Darendeliler et al (20). The final height SDSs in the IGHD and MPHD groups in our study, with a similar dose range but shorter median treatment time, were similar to other studies from our country. It was thought that the better response in our patients in the MPHD group was associated with lower IGF-1 and peak GH values in the $\mathrm{GH}$ stimulation tests, as well as lower chronological age and bone age at the beginning of treatment compared with patients with IGHD.

The effect of GH treatment on final height in TS is variable and many factors, such as polymorphisms associated with the $\mathrm{GH}$ receptor and/or IGFBP3 gene, age at the beginning of treatment, dose of $\mathrm{GH}$, duration of treatment, bone age retardation, maternal $\mathrm{X}$ chromosome origin, first year response to target height, and oxandrolone treatment affect the treatment response $(21,22,23)$. The IGFBP3 gene promoter region contains several single nucleotide polymorphisms (SNPS). The 202 A/C SNP which located 202 bp upstream of the transcription start site consists of an $A$ to $\mathrm{C}$ nucleotide change and is correlated with serum IGFBP-3 concentrations in healthy adults. Serum IGFBP-3 levels are highest in patients with the AA genotype, followed by the AC and CC genotypes (24). An association of the A allele in the IGFBP-3 promoter region with increased IGFBP-3 concentration and growth velocity after GH therapy has been observed in prepubertal children with GHD and TS $(25,26)$.

Recently Ahn et al (27), in a study of 73 patients with TS, reported that the height SDS at the beginning was correlated with final height SDS, and that early treatment was very important. Evaluation of the data of 70 TS patients registered from 11 centers in Turkey in the KIGS database who received $\mathrm{GH}$ at a dose of $33 \mu \mathrm{g} / \mathrm{kg} / \mathrm{d}$ subcutaneously, 6-7 times per week, with onset of therapy at age 12.5 (7.1 15.6) years revealed a non-significant increase in growth velocity $6.3 \mathrm{~cm} /$ year in the first year and $5.9 \mathrm{~cm} /$ year in the second year (28). In another study in which 842 patients with TS were evaluated with the participation of 35 centers from our country, it was reported that the average age to diagnosis with TS was $10.5 \pm 4.8$ years and that treatment was initiated at the age of $10.7 \pm 3.5$ year (29). In our study, the age at onset of treatment, the dose of treatment, and the first year response to treatment in patients with TS were consistent with earlier studies from our country, and although there was no significant difference in terms of height SDS between GH treatment initiation and cessation times, the rate of reaching the target height was the lowest in the TS group. We hypothesize that this was due to the age at onset of treatment being late in our patients and that the height SDS at the beginning of treatment were significantly lower.

$\mathrm{GH}$ treatment in infants with SGA is effective in the correction of body composition and improvement of metabolic complications, in addition to its contribution to stature in adulthood (30). The dose recommended by the Pediatric Endocrinology and Growth Hormone Research Society in children with SGA is $35-70 \mathrm{mg} / \mathrm{kg} /$ day, and higher doses are recommended for patients with severe growth retardation. Treatment dose, age at initiation, height at initiation of treatment, and mid-parental height are among the factors affecting the response of GH in children with SGA (31). The multidisciplinary follow-up of many of the SGA cases by other departments in our hospital has caused these patients to be referred to our clinic earlier and to start treatment earlier because of earlier diagnosis of growth disorders. However, there was no significant difference between $\mathrm{GH}$ treatment initiation and cessation in terms of height SDSs in the SGA group and the final height SDS was the lowest in the SGA group. These findings were thought to be due to the fact that the doses used in the SGA group were at the lower limit of the recommended dose and were associated with a treatment mismatch in this group.

In this study, although the chronological age and bone age were higher in the pubertal IGHD patients and the duration of GH treatment was longer in the prepubertal IGHD patients, there was no statistically significant difference between the two groups in terms of final height SDS. Similarly, Kurnaz et al's (19) study did not show a difference in final height SDS 
of prepubertal and pubertal patients, but it was reported that delta height SDS was higher in pubertal patients (20). These results suggest that even if the $\mathrm{GH}$ treatment is initiated at pubertal age, it may be beneficial in achieving a final height compatible with the genetic potential together with the pubertal growth spurt.

Finally, our results justify the incorporation of height SDS at the beginning of treatment, target height SDS, and first-year response to treatment as major parameters in all predictive models of final height in all GH-treated children $(21,32,33)$.

\section{Study Limitations}

The main limitations of this study are that it was designed retrospectively and the number of patients who could be evaluated in terms of final height was low.

\section{Conclusion}

This study has shown that GH treatment was started late in the entire group and there was no improvement in the 10 year study period. It was observed that patients who were admitted with short stature received $\mathrm{GH}$ treatment approximately 1.5 years later and this is likely to have negatively affected treatment responses. We suggest that efforts should be made to reduce the period between first presentation at the pediatric endocrinology clinic and initiation of GH therapy, if indicated. As a result of late start of GH treatment, improvement in the height SDSs of SGA and TS groups was minimal. In the IGHD group, it was seen that approximately $68 \%$ of those who reached final height also achieved the target height. Treatment compliance of patients receiving GH treatment was high.

Although our results cannot be generalized for the whole country, we believe that GH treatment probably does not show significant regional difference, the data obtained from large patient series are important, and in this context, our study may reflect the current situation in GH treatment in our country. Therefore, the results of this study suggest that clinical awareness of causes of short stature should be improved, diagnosis in patients with pathological short stature should be more rapid, the period between first presentation at pediatric endocrinology and initiation of GH therapy should be shortened and that in all children who would benefit from GH therapy, treatment should be started at earlier ages.

\section{Ethics}

Ethics Committee Approval: The study was conducted in accordance with the principles of the Declaration of Helsinki and approved by a Ankara Keçiören Training and
Research Hospital Local Ethics Committee (no: 1686, date: 23.05.2018).

Informed Consent: The study was retrospective and no interventions were used. Therefore we did not obtain informed consent from the patients or their parents.

Peer-review: Externally and internally peer-reviewed.

\section{Authorship Contributions}

Medical Practices: Aslıhan Araslı Yılmaz, Servet Yel, Zehra Aycan, Concept: Zehra Aycan, Şenay Savaş-Erdeve, Semra Çetinkaya, Design: Zehra Aycan, Şenay Savaş-Erdeve, Semra Çetinkaya, Data Collection or Processing: Aslihan Araslı Yllmaz, Servet Yel, Zehra Aycan, Analysis or Interpretation: Aslıhan Araslı Yılmaz, Servet Yel, Zehra Aycan, Şenay SavaşErdeve, Semra Çetinkaya, Literature Search: Aslihan Araslı Yılmaz, Zehra Aycan, Writing: Aslıhan Araslı Yılmaz, Zehra Aycan.

Financial Disclosure: This study was unrequitedly funded by Pfizer Turkey.

\section{References}

1. Ranke M, Wit J. Growth hormone-past, present and future. Nat Rev Endocrinol 2018;14:285-300. Epub 2018 Mar 16

2. Collett-Solberg PF, Jorge AAL, Boguszewski MCS, Miller BS, Choong CSY, Cohen P, Hoffman AR, Luo X, Radovick S, Saenger P. Growth hormone therapy in children; research and practice -a review. Growth Horm IGF Res 2019;44:20-32. Epub 2018 Dec 26

3. Ranke MB, Lindberg A, Tanaka T, Camacho-Hübner C, Dunger DB, Geffner ME. Baseline characteristics and gender differences in prepubertal children treated with growth hormone in Europe, UAS, and Japan: 25 years' KIGS experience (1987-2012) and review. Horm Res Paediatr 2017;87:30-41. Epub 2016 Dec 3

4. Kaplowitz PB, Shulman DI, Frane JW, Jacobs J, Lippe B. Characteristics of children with the best and poorest first- and second-year growth during rhGH therapy: data from 25 years of the Genentech national cooperative growth study (NCGS). Int J Pediatr Endocrinol 2013:9.

5. Polak M, Konrad D, Tønnes Pedersen B, BT Puras, Šnajderová M. Still too little, too late? Ten years of growth hormone therapy baseline data from the NordiNet ${ }^{\circledR}$ International Outcome Study. J Pediatr Endocrinol Metab 2018;31:521-532.

6. Schoenfeld A, Redberg R. The value of using registries to evaluate randomized clinical trial study populations. JAMA Intern Med 2017;177:889.

7. Growth Hormone Research Society Consensus guidelines for the diagnosis and treatment of growth hormone (GH) deficiency in childhood and adolescence: summary statement of the GH research society. J Clin Endocrinol Metab 2000;85:3990-3993.

8. Gravholt $\mathrm{CH}$, Andersen NH, Conway GS, Dekkers OM, Geffner ME, Klein KO, Lin AE, Mauras N, Quigley CA, Rubin K, Sandberg DE, Sas TCJ, Silberbach M, Söderström- Anttila V, Stochholm K, van Alfenvan derVelden JA, Woelfle J, Backeljauw PF; International Turner Syndrome Consensus Group. Clinical practice guidelines for the care of girls and women with Turner syndrome: proceedings from the 2016 Cincinnati International Turner Syndrome Meeting. Eur J Endocrinol 2017;177:G1-G70. 
9. Rosenfield RL, Cooke DW, Radovick S. Puberty and its disorders in the female. In: Sperling $M$, ed. Pediatric Endocrinology. 4th ed. Philadelphia, PA, Elsevier, 2014;569-663.

10. Neyzi O, Günoz H, Furman A, Bundak R, Gokcay G, Darendeliler F, Bas F. Weight, height, head circumference and body mass index references for Turkish children. Çocuk Sağlığı ve Hastalıkları Dergisi 2008;51:1-14.

11. Kurtoğlu S, Hatipoğlu N, Mazıcıoğlu MM, Akın MA, Çoban D, Gökoğlu $\mathrm{S}$, Baştuğ $\mathrm{O}$. Body weight, length and head circumference at birth in a cohort of Turkish newborns. J Clin Res Pediatr Endocrinol 2012;4:132139. Epub 2012 May 4

12. Tanner JM, Goldstein H, Whitehouse RH. Standards for children's height at ages 2-9 years allowing for heights of parents. Arch Dis Child 1970;45:755-762

13. Smith SL, Hindmarsh PC, Brook CG. Compliance with growth hormone treatment- are they getting it? Arch Dis Child 1993;68:91-93.

14. Darendeliler F, Berberoğlu M, Öcal G, Adiyaman P, Bundak R, Saka N, Baş F, Darcan Ş, Gökşen D, İşgüven P, Yildiz M, Ercan O, Ercan G, Özerkan E, Can Ş, Büyükgebiz A, Böber E, Adal E, Sarikaya S, Dallar Y, Şiklar Z, Bircan İ, Bideci A, Yüksel B. Büyüme hormonu eksikliği etiyolojisi, demografik veriler ve tedavi sonuçlarının değerlendirilmesi: Türkiye verileri. KIGS analiz sonuçları. Çocuk Dergisi 2004;4:141-148.

15. Kosteria I, Aloumanis K, Kanaka-Gantenbein C, Vlachopapadopoulou E, Michalacos S, Stamoyannou L, Drossinos E, Chrousos G. Pediatric growth hormone therapy in Greece: analysis of the Hellenic cohort of the GeNeSIS study. Hormones (Athens). 2019;18:423-434. Epub 2019 Nov 6

16. Sävendahl L, Polak M, Backeljauw P, Blair J, Miller BS, Rohrer TR, Pietropoli A, Ostrow V, Ross J. Treatment of children with GH in the United States and Europe: long-term follow-up from NordiNet ${ }^{\circledR}$ IOS and ANSWER program. J Clin Endocrinol Metab 2019;104:4730-4742.

17. Pfäffle R, Land C, Schönau E, Holterhus PM, Ross JL, Piras de Oliveira C, Child CJ, Benabbad I, Jia N, Jung H, Blum WF. Growth hormone treatment for short stature in the USA, Germany and France: 15 years of surveillance in the Genetics and Neuroendocrinology of Short-Stature International Study (GeNeSIS). Horm Res Paediatr 2018;90:169-180 Epub 2018 Sep 10

18. Soyöz Ö, Dündar B. Büyüme hormonu tedavisi alan çocukların klinik özellikleri ve tedaviye yanıtı etkileyen faktörler. İzmir Katip Çelebi Üniversitesi Sağlık Bilimleri Fakültesi Dergisi 2016;1:7-13.

19. Kurnaz E, Çetinkaya S, Aycan Z. Near final height in patients with idiopathic growth hormone deficiency: A single-centre experience. J Paediatr Child Health 2018;54:1221-1226.

20. Darendeliler F, Lindberg A, Wilton P. Response to growth hormone treatment in isolated growth hormone deficiency versus multiple pituitary hormone deficiency. Horm Res Paediatr 2011;76(Suppl 1):4246. Epub 2011 Jul 21

21. Ranke MB, Lindberg A, Ferrández Longás A, Darendeliler F, AlbertssonWikland K, Dunger D, Cutfield WS, Tauber M, Wilton P, Wollmann HA, Reiter EO KIGS International Board. Major determinants of height development in Turner syndrome (TS) patients treated with GH: analysis of 987 patients from KIGS. Pediatr Res 2007;61:105-110

22. Davenport ML. Growth hormone therapy in Turner syndrome. Pediatr Endocrinol Rev 2012;9(Suppl 2):723-724.

23. Özgen İT, Adal E, Ünüvar T, Önal H, Sarıkaya AS, Akın L. Response to growth hormone therapy in patients with Turner syndrome. Turk Arch Ped 2013;48:294-298.

24. Deal C, Ma J, Wilkin F, Paquette J, Rozen F, Ge B, Hudson T, Stampfer M Pollak M. Novel promoter polymorphism in insulin-like growth factorbinding protein-3: correlation with serum levels and interaction with known regulators. J Clin Endocrinol Metab 2001;86:1274-1280.

25. Costalonga EF, Antonini SR, Guerra-Junior G, Mendonca BB, Arnhold IJ, Jorge AA. The -202 A allele of insulin-like growth factor binding protein-3 (IGFBP3) promoter polymorphism is associated with higher IGFBP-3 serum levels and better growth response to growth hormone treatment in patients with severe growth hormone deficiency. J Clin Endocrinol Metab 2009;94:588-595. Epub 2008 Nov 4

26. Braz AF, Costalonga EF, Montenegro LR, Trarbach EB, Antonini SR, Malaquias AC, Ramos ES, Mendonca BB, Arnhold IJ, Jorge AA. The interactive effect of GHR-exon 3 and -202 A/C IGFBP3 polymorphisms on rhGH responsiveness and treatment outcomes in patients with Turner syndrome. J Clin Endocrinol Metab 2012;97:E671-E677. Epub 2012 Jan 25

27. Ahn JM, Suh JH, Kwon AR, Chae HW, Kim H-S. Final Adult height after growth hormone treatment in patients with turner syndrome. Horm Res Paediatr 2019;91:373-379. Epub 2019 Sep 3

28. Darendeliler F, Bas F, Berberoglu M, Öcal G, Günöz H. Darcan Ş, Bundak R Arslanoğlu İ, Yüksel B, Bideci A. Turner Sendromunda büyüme hormonu tedavi sonuçlarının değerlendirilmesi: Türkiye KIGS verileri (Pfizer Uluslararası büyüme veritabanı) veritabanı analiz sonuçları. Çocuk Dergisi 2005;5:21-26.

29. Yeşilkaya E, Bereket A, Darendeliler F, Baş F, Poyrazoğlu Ş, Küçükemre Aydin B, Darcan Ş, Dündar B, Büyükinan M, Kara C, Sarı E, Adal E, Akıncı A, Atabek ME, Demirel F, Çelik N, Özkan B, Özhan B, Orbak Z, Ersoy B, Doğan M, Ataş A, Turan S, Gökșen D, Tarım Ö, Yüksel B, Ercan O, Hatun Ş, Şimşek E, Ökten A, Abacı A, Döneray H, Özbek MN, Keskin M, Önal H, Akyürek N, Bulan K, Tepe D, Emeksiz HC, Demir K, Kızılay D, Topaloğlu AK, Eren E, Özen S, Abalı S, Akın L, Selver Eklioğlu B, Kaba S, Anık A, Baş S, Ünüvar T, Sağlam H, Bolu S, Özgen T, Doğan D, Deniz Çakır E, Şen Y, Andıran N, Çizmecioğlu F, Evliyaoğlu O, Karagüzel G, Pirgon Ö, Çatlı G, Can HD, Gürbüz F, Binay Ç, Baş VN, Fidancı K, Polat A, Gül D, Açıkel C, Demirbilek H, Cinaz P, Bondy C. Turner syndrome and associated problems in Turkish children: a multicenter study. J Clin Res Pediatr Endocrinol 2015;7:27-36.

30. Zanelli SA, Rogol AD. Short children born small for gestational age outcomes in the era of growth hormone therapy. Growth Horm IGF Res 2018;38:8-13. Epub 2017 Dec 28

31. Clayton PE, Cianfarani S, Czernichow P, Johannsson G, Rappaport R, Rogol. A. Management of the child born small for gestational age through to adulthood: a con-sensus statement of the International Societies of Paediatric Endocrinology and the Growth Hormone Research Society. J Clin Endocrinol Metab 2007;92:804-810. Epub 2007 Jan 2

32. Land C, Blum WF, Shavrikova E, Kloeckner K, Stabrey A, Schoenau E. Predicting the growth response to growth hormone $(\mathrm{GH})$ treatment in prepubertal and pubertal children with isolated GH deficiency--model validation in an observational setting (GeNeSIS). J Pediatr Endocrinol Metab 2007;20:685-693.

33. Ranke MB, Lindberg A; KIGS International Board. Height at start, first-year growth response and cause of shortness at birth are major determinants of adult height outcomes. of short children born small for gestational age and Silver-Russell syndrome treated with growth hormone: analysis of data from KIGS. Horm Res Paediatr 2010;74:259. 266. Epub 2010 Apr 30 